\title{
Marxism: The Next Two Decades University of Manitoba, Winnipeg, Canada 12-15 March 1983
}

\section{Bryan Palmer}

Vancouver, Canada

In an unprecedented event, almost 800 people gathered in Winnipeg to commemorate the centenary of Marx's death with a conference addressed to the pressing concerns Marxists and Marxism will face in the last two decades of the twentieth century. Over the course of four days 23 sessions convened, punctuated by film showings, informal gatherings, and cultural events. The sessions separated themselves into two overlapping areas, those concerned primarily with theory (class structure, political economy, the changing character of the international division of labour, Marx \& Keynes, or the current crisis of Marxism) and those turning on more practical concerns (organizing popular movements, the nature and place of vanguard parties, labour's response to the crisis, or feminist critiques of socialist organization). But the sessions were all an attempt to bridge this gap between theory and practice, and to infuse both with an internationalism reflected in the participants and panelists. Those in attendance came from Europe, the United States, and Canada, from the labour movement and the University, from the left organizations (many of them in a current state of considerable disarray) and the established social democratic milieu.

They also came from both genders. Indeed, the woman question, or as it is increasingly known as, the male problem, was perhaps the single most pressing issue at the conference. An opening night plenary, a rare oportunity for all participants to come together, addressed the theme of women and the current crisis, and each day following saw specific smaller sessions or particular papers within more general sessions devoted to feminist critique. Ten years ago this would never have happened. But women's involvement in the Marx Conference, and the centrality of gender relations in all discussions, both theoretical and practical, highlights the extent to which women have fought their way into Marxism. demanding a hearing. Such battles are not without their costs. Zillah Eisenstein's spirited defence of sex as class became translated, in presentations by Geraldine Finn, into a literal repudiation of working-class organization, economic militancy. and political protest as malestream forms of resistance structured inevitably along patriarchal lines. One was left wondering what Marx would have made of all of this. And when Dorothy Smith, whose own pronouncements at the Conference constantly returned to the need to address 
political and social change in language and tone far removed from the past practices of the left. condemned Eisenstein's presentation as the philistinism of the petty bourgeoisie it was all too clear that there were many differences floating among the participants. As the panel on feminist critiques of socialist organization indicated, with Marlene Dixon lambasting the audience for their lack of class analysis and class program. consensus was an elusive end: the level of contradiction throughout the discussions was at times enough to make the most dialectical of Maoists beat a hasty retreat.

This diversity was evident from the Conference's opening shots, when Leo Panitch. Goran Therborn, and Ralph Miliband walked ine of an intellectual assessment of social democracy's limitations. while I ynn MacDonald jumped over it to assert defensively that in the here and now of Canadian politics the New Democratic Party was where it was at. The audience was, if the response from the floor was any indication, having none of the scholasticism or sophism of the speakers. opting instead for sectarianism. In sessions that followed there was to be more of this. with speakers and audience debating the role of the Soviet Union, the nature of the class struggle, or the validity of specific socialist strategies in the Third World.

Highlights of the Conference. within this general diversity of views, included Ralph Miliband's hard-hitting defence of the continuities of class struggle in times of apparent working-class retreat. Stanley Ryerson's attempt to address the relevance of Marxism in the final quarter of the twentieth century, and Leo Panitch's wonderfully entertaining outline of what labour is doing and what it can do during the current economic collapse. But such performances were tarnished by the overly ambitious program of which they were a part. Miliband's and Ryerson's talks, for instance were sandwiched into an unwieldy session entitled "The International Division of I abor. Class Struggle, and the Labour Process," and they were delivered alongside of two highly academic presentations that would have fit far more comfortably into the meetings of the American Economists Sociologists Association(s). The talk by Panitch, which might have roused us all, was a perfect complement to the remarks of his co-panelists, labour movement figures Judy Darcy and John Calvert. But it took place at 9:30 at night. after many in the hall had been in attendance since $8: 30$ in the morning. It was just too much, and with transportation, daycare and food facilities being poor many found the 14 hour days a little trying.

In the end. then. many left the conference disappointed and confused, tired and worn out. But there was also a sense that in the discussions and in the diversity something was in the air: a movement away from the sectarianism that has kept so much of the Marxist left hived off from both its constituency---the working class-and its component parts. New developments were being talked out at the Conference, in the sessions and in informal meetings. If many divisions and differences remained, and if much was left to do (there was all too little discussion of unemployment, racism, the peculiarities of Canadian regionalism, or the current war drive) the participants of the Conference saw possibilities ahead. With the international capitalist order in general and the Canadian political economy in particular 
caught in the vise of crisis, with the survival of civilization as we have come to know it threatened by the escalation of the arms race in the atomic age. possibility is what must be grasped most vigorously and thrust in the face of those class forces and structures that aim to thwart it. The Marx Conference in Winnipeg, if it did nothing else, did impress that upon many people. 